\title{
Wal-Mart and Small Business: Boon or Bane? ${ }^{+}$
}

Michael J. Hicks*

\begin{abstract}
This paper tests the impact of Wal-Mart discount and superstore presence on the number of small businesses in Iowa counties from 1989-2003. I employ and compare two well-known identification strategies in a spatial autoregressive model. I find no statistically meaningful impact of Wal-Mart on small firms (1-20 employees in three employment ranges), though there is weak statistical evidence that an own-county Wal-Mart increases the number of small businesses while Wal-Marts in adjacent counties reduce the number of small businesses. These results mimic several other studies of Wal-Mart including Hicks and Wilburn (2001), Hicks (2007), and Sobel and Dean (2008).
\end{abstract}

Key Words: Wal-Mart, big box retail, Iowa.

JEL Classifications: R1, R51

\section{INTRODUCTION}

Whenever a new Wal-Mart opens, small businesses-from dress shops and pharmacies to hardware, auto supply and music stores—close their doors and good jobs disappear.

\section{-AFL-CIO Website}

Few issues surrounding local employment dynamics are as contentious as the impact of a new Wal-Mart store on small businesses. Consequentially, policymakers are in need of credible estimates regarding the putative impact of Wal-Mart on small businesses.

Shortly, I review a number of studies on Wal-Mart that examine the impact of the store on competing retailers, the structure of the industry, the price of goods, and other aspects ranging from state-level union participation to sprawl. Like the present study, many of these papers offer discrete impact modeling, rather than a more detailed examination of producer and consumer surplus. The purpose of choosing small businesses as a focus of analysis is two-fold. First, I wish to update previous analyses with the most modern modeling approach to the problem; second, I wish to revisit the major piece of policy debate on the matter. This paper provides estimates of Wal-Mart's impact on small businesses in the state of Iowa. I proceed with a review of the research to date, followed by a description of the data and region to be analyzed, a description of the model, and econometric considerations and results. I end with a comparison of these findings to other research on Wal-Mart and policy recommendations.

\section{THE LITERATURE}

Estimates of Wal-Mart's influence on local economies began with Stone's (1989) study of small towns and communities in Iowa. Stone offered mixed evidence of the impact, noting increased retail sales in cities with Wal-Mart. However, he found that the net effect on retail

\footnotetext{
${ }^{+}$The author of this study owns no stock in Wal-Mart or any related firm (other than that held by the mutual fund companies). I have performed no paid-consulting services for any retail firm, its developers, local governments, or related entities since 2002 (though I continue to field frequent questions on my earlier research). In short, except for roughly $\$ 1,500$ in purchases of diapers annually since 1999, I am unaware that I have had any financial relationship with Wal-Mart or any of its affiliates.

* Hicks is the Director of the Center for Business and Economic Research and an Associate Professor of Economics at the Miller College of Business, Ball State University, Muncie, IN 47306; E-mail: mhicks@bsu.edu. 
sales is less than the total sales of a new Wal-Mart, clearly suggesting that some existing retail trade is lost to a new Wal-Mart. The impact of Wal-Marts on area sales fades over time, and Wal-Mart stores that located outside of small towns reduced retail businesses within those small towns, even where the Wal-Mart store yielded an overall positive impact on local retail sales. In essence, Stone found somewhat mixed results on nearby retail. His results became among the most-cited estimates in both the popular media and in the policy debates surrounding new WalMart stores throughout the nation.

Unfortunately, this initial study of Stone's suffers from two great weaknesses. First, it makes no attempt to isolate the impact of Wal-Mart on retail employment ceteris paribus, and second, it fails to consider the potential endogeneity of Wal-Mart's entrance decision with respect to local economic conditions. Even today, these problems plague much of the literature on the net local-area economic effects of big box stores.

Two studies by Franz and Robb (1989) and Ozment and Martin (1990), which were nearly simultaneous released, examine the impact of Wal-Mart on the structure of retail markets. Both studies report modest positive impacts on wages, employment, and number of businesses within counties with Wal-Mart stores. The first study is a survey of local businesses, while the second tests data on the number of firms. Ozment and Martin also note the possibility that WalMart's choice of faster-growing counties as potential new store sites may distort their findings.

Barnes et al. (1996) and Ketchum and Hughes (1997) examine Wal-Mart's impact while attempting to control for preexisting conditions in regions. Both teams examine retail sales and employment growth, yet found no evidence of any increase in the number of retail firms in the wake of Wal-Mart openings. Barnes et al. find a modest decline in the number of specialty retail stores at the county level. Many subsequent studies confirm these findings (see Artz, 1999; Artz and McConnon, 2001; Hornbeck, 1994; McGee and Gresham, 1995; Stone, Artz, and Myles, 2002; Mehta, Baiman, and Persky, 2004). Still, these studies suffer some fundamental common weaknesses (e.g., absence of convincing controls for underlying economic conditions, and potential concern over selection bias or the sub-regions that are examined). Further, several of these studies avoid statistical comparisons of impacts, even those that use a quasi-experimental approach. A remarkably large number of local impact studies (not cited here, due to the overwhelming number of them) follow these trends of naïvely using employment and firm accounting in attempts to analyze the net impact of Wal-Marts. For policymakers, these studies offer few concrete conclusions, for none speak convincingly or comprehensively of Wal-Mart's net economic impacts.

Franklin (2001) and Hicks and Wilburn (2001) first modeled the entrance of Wal-Marts econometrically. Franklin examined food stores in Metropolitan Statistical Areas wherever WalMart supercenters had opened, while Hicks and Wilburn examined retail industry structure, wages, and employment in West Virginia counties. In both studies, the authors regressed various growth factors on a binary entrance variable and rejected the possibility that Wal-Mart tended to select only counties with high retail growth potential. Hicks and Wilburn found a very small, positive effect of Wal-Mart entry on county retail industry structure (four to five new firms). Interestingly, they also found an "adjacent to Wal-Mart" effect. That is, they found that counties adjacent to those containing a newly opened Wal-Mart subsequently were hit with a statistically meaningful but economically trivial loss of firms (less than one firm loss spread out across an average of four adjacent counties). 
Basker (2005a) estimated Wal-Mart's impact on a subset of growing and urban U.S. counties, focusing on employment and industry structure. She treated potential endogeneity by using the planned entrance date of Wal-Mart (roughly two years prior to actual opening) to identify economic conditions within the county during the subsequent entrance. She found a modest loss of small retail firms, and a small growth in retail employment. Further, by employing a polynomial distributed lag, Basker illustrated the rate of adjustment in local retail markets.

Neumark, Zhang, and Ciccarella (2008) (henceforth, N-Z-C) similarly estimated the economic effects of Wal-Mart on U.S. counties across several sample sets (to narrow concerns regarding endogeneity of entrance). They identified the model spatially using an instrument that captures the distance from newly opened Wal-Marts from the original store in Benton County, Arkansas and using a time variable that indexed annually from the opening of the first store in 1962. N-Z-C also used a variable that was the multiplicative interaction of these two. N-Z-C found employment declines of up to four percent in some specifications.

A third strategy to account for Wal-Mart's entrance decision was put forward by Hicks and Wilburn (2007), who incorporated a specific comment by a Wal-Mart official regarding market size as a key location strategy. Accordingly, the authors used the total personal income in a county (and contiguous counties) to identify the impact equation. Hicks also compared the three identification techniques (Basker, 2005a; Neumark, Zhang, and Ciccarella, 2008; and Hicks, 2007b) finding very modest estimate differences. Testing only on Maryland to avoid concerns over cross-state fiscal differences bias in the estimates, Hicks and Wilburn found that new Wal-Marts tend to yield modest reductions in employment in urban areas, employment increases in rural areas, and small positive wage impacts in the retail sector everywhere. They contended that this finding is similar to that of Dube, Eidlin, and Lester (2006) who used an identification strategy similar to that used by N-Z-C.

Using a series of counterfactuals, however, Basker (2007), criticizes N-Z-C's instrument and treatment equation. She finds that their estimates of Wal-Mart's impact actually explains growth in manufacturing employment - a very unlikely outcome she attributes to model misidentification.

Hicks (2008) reviews these techniques as well as the range estimates of Wal-Mart's impact on labor and goods markets. His study describes the struggle to correctly identify a model of Wal-Mart's entrance across competing specification and identification strategies, and compares the results of three different approaches.

Sobel and Dean (2008) estimate Wal-Mart's impact on small business at the state level, employing a panel spatial autoregressive model. They find no discernable impact on small business across several specifications. Further, they critique Stone's $(1989,1995)$ estimates of Wal-Mart's impact on retail through the careful extrapolation of his findings to later Wal-Mart entrance. They argue that Stone's findings suggest a profound decrease in "mom and pop" stores, when in fact growth in small business in Iowa has outpaced population growth since 1989. 
Figure 1: Carroll County, Iowa Small Businesses and Wal-Mart

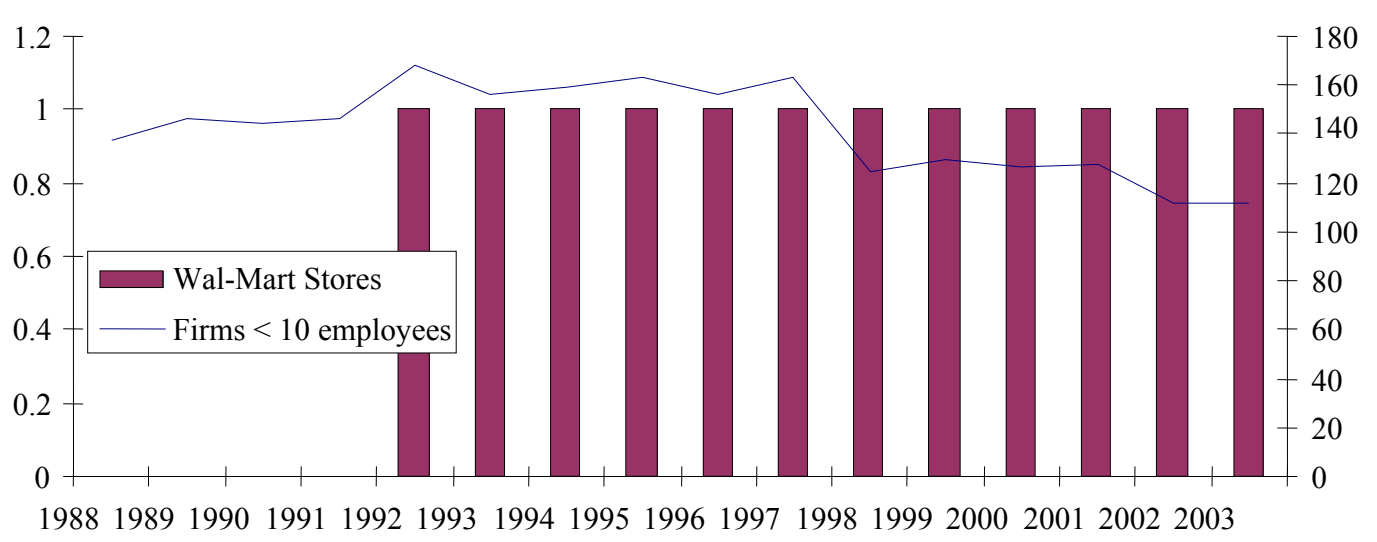

Hicks (2007) revisits Stone's estimates on pull factors at the county level. This analysis, which employs endogeneity corrections, refutes roughly 8 out of 10 impacts as statistically negligible. The magnitudes of remaining impacts rise to modest levels of statistical significance and range from 10 to 50 percent of those reported by Stone. Clearly, the issue of Wal-Mart's impact on small business in Iowa warrants additional scrutiny.

\section{THE LOCATION, DATA, AND MODEL}

The choice of Iowa as a prime locale for examining Wal-Mart's impact on small business warrants some comment. First of all, Iowa also enjoys a rather heterogeneous rural-urban population distribution. It also has a rather large number of counties, which when coupled with an extensive history of Wal-Mart exposure (since the mid-1980s) and study, make Iowa an attractive location for evaluating Wal-Mart's impact. The reason for the long history of study is made most apparent from an example of a Wal-Mart experience shown in Figure 1. Carrol County, Iowa, experienced a noticeable decline in small retail (general merchandise) stores in the years following a Wal-Mart opening there. Iowa is also a good choice for analysis because of its geography. The state has a fairly regular county distribution with counties that are largely of the same geographic size and adjoin fairly regular sets of adjacent counties (Figure 2).

Data for the analysis presented here were obtained from several well-known sources. County Business Patterns provided the detailed retail data for number of firms by employment classification. Additional economic data at the county level were obtained from the Bureau of Economic Analysis' Regional Economic Information System.

Definitions of the term "small business" vary dramatically. For our purposes, we include retail firms in the three smallest categories reported by County Business Patterns: 1-4 employees, 5-9 employees and 10-19 employees. The intent here is to target non-chain stores or small chain stores selling traditional retail (non-food) items. There are inherent challenges in modeling this type of issue. The data tell us the general category of market in which the firm might sell, but is silent on the product mix of individual firms. So, we cannot estimate the effects of Wal-Mart on a firm's product mix, or on type of retail goods within a general category. This is an interesting 


\section{Figure 2: Iowa County Map}

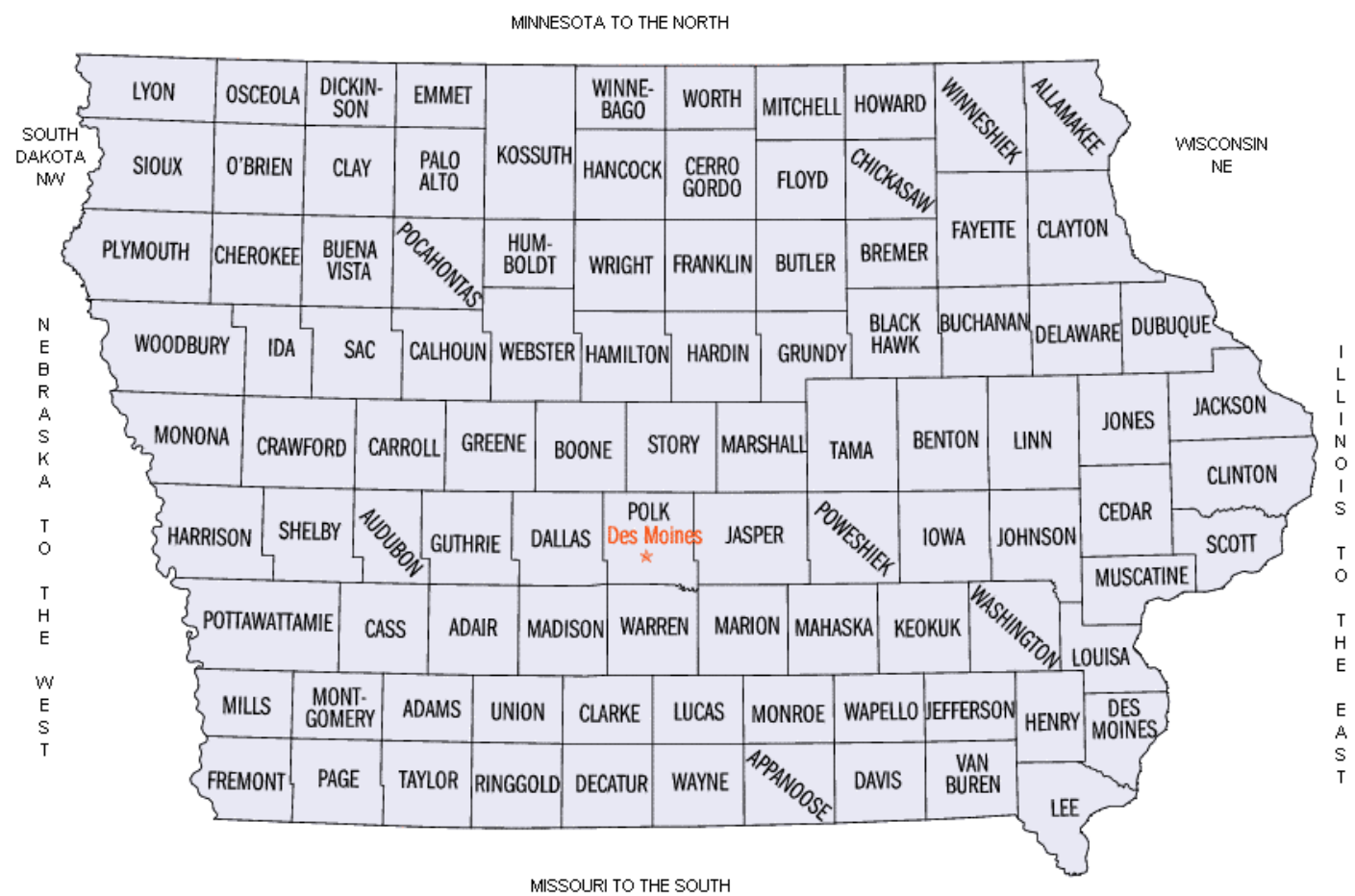

Source: US Census.

topic since business analysts tend to caution firms to avoid direct price competition with WalMart and, instead, to focus on altering their quality and service dimensions (see Stone, 1995, and Rigby and Haas, 2004).

Another concern is that during the study period, the official Federal classification system for industries switched from the Standard Industrial Classification (SIC) to the North American Industrial Classification System (NAICS). The result is a set of changes in pertinent data series that are small but nontrivial. About 3.3 percent of the SIC count of retail establishments was lost due to changes in industry definitions. ${ }^{1}$ The relevant changes occurred, however, almost wholly within Eating and drinking establishments, Accommodations, and changes from Retail to Wholesale designation (wholesaling establishments owned by retailers). Thus, it is unlikely that series critical to the present study would be affected since they tend to be affiliated with larger, chain retail firms. Still, we tested coefficients across year 2000, when the series break occurred. The Chow test was not statistically significant ( $p$ value $>.60$ ). Hence it seemed unlikely the SICto-NAICS conversion was problematic for introducing noticeable sample bias in this model.

The time and location of each Wal-Mart opening is available from a data release by the retailer after a November 2005 conference on the economic consequences of Wal-Mart. Further, Wal-Mart stores essentially come in two types: traditional stores and supercenters. Supercenters contain a grocery store and often concentrations of products and services similar to other retail outlets such as pharmacies, small restaurants, optometrists, and beauty salons. These are likely to

\footnotetext{
${ }^{1}$ See Department of the Census http://www.census.gov/mrts/www/naics/retcomp.pdf
} 
Table 1: Summary of Key Statistics on Iowa Counties, 1989-2003

\begin{tabular}{lrrrrr} 
& Mean Median & Maximum & Minimum Std. Dev. \\
\hline \hline Wal-Mart Presence & 0.20 & 0 & 4 & 0 & 0.441 \\
Adjacent Wal-Mart Presence & 0.22 & 0 & 1.75 & 0 & 0.302 \\
Aggregate County Personal Income (\$ million) & 426,462 & 204,806 & $13,614,957$ & 19,620 & 892,347 \\
$n=1,485$, with 99 Cross Sections & & & & & \\
\hline \hline
\end{tabular}

have a slightly different set of competing small businesses. Since 1990, Wal-Mart has been transforming its traditional stores into supercenters. Still, we treat the entrance of a Wal-Mart and a Wal-Mart supercenter as the same phenomenon, since the upgrade to a supercenter is not something that can be readily identified. A summary of these key data appear in Table 1.

As part of an identification strategy, the distance of each Wal-Mart to the original store in Benton County, Arkansas, was calculated using commercial mapping software: the measurements are driving distances. This differs from the two other distance instruments reviewed above, which are Mahalanobis distances, but is identical to that used by Hicks (2008).

In order to explicitly evaluate Wal-Mart's impact on small businesses, I begin with a pure treatment model of Wal-Mart's impact:

$$
\Theta_{i, t}=\alpha+\alpha_{i}+\beta_{1} W M_{i, t}+\beta_{2} W M_{j, t}+\beta_{3} \tilde{W}_{j, t} \Theta_{j, t}+\delta \phi_{i, t-1}+e_{i, t},
$$

where the number of small retail businesses in each size category $\Theta$, is a function of a common $(\alpha)$ and a cross-section-specific $\left(\alpha_{i}\right)$ intercepts, a cross-section- and time-specific Wal-Mart presence/count variable $\left(W M_{i, t}\right)$, a time-specific count of Wal-Marts in $j$ adjacent counties $\left(W M_{j, t}\right)$, a time- and cross-section specific spatial weight $\left(\tilde{W}_{j, t}\right)$, a first-order spatial lag of the dependent variable $\left(\Theta_{j, t}\right)$, and a first-order autoregressive variable $\left(\phi_{i, t-1}\right)$, and a white noise error term $\left(e_{i, t}\right)$. These data are stationary, so we estimate them in their levels. ${ }^{2}$

The specification of a spatial lag requires some discussion. Hicks and Wilburn (2001) reported a very strong spatial element to retail trade over 1988-2001, which covers much of the present study's period. They found that Wal-Mart entry reduced both retail employment and number of firms in adjacent counties in a spatial model of West Virginia. Of course, omitting adjacent county effects in own-county entrance would be a serious modeling concern in this setting.

As with previous analyses of Wal-Mart's impacts, we are concerned about the potential for endogeneity. Simply put, the endogeneity issue here is that if Wal-Mart is systematically entering markets with a growing number of retail stores, then estimates will be biased towards finding a positive effect of Wal-Mart. Recall, however, that there remains considerable debate over the appropriate means of correcting for the endogeneity bias we encounter here (Basker, 2005a; Hicks, 2008; and Neumark, Zhang, and Ciccarrella, 2008). While endogeneity remains a most significant econometric concern, strategies controlling for it do have costs. The first choice in limiting endogeneity bias is through employing a pure treatment model. The endogeneity

\footnotetext{
${ }^{2}$ I conducted individual unit root tests (Augmented Dickey-Fuller) on personal income data from 1989 through 2003 as these were my greatest concern for nonstationarity. I performed grouped unit root tests on the Wal-Mart presence and adjacent WalMart presence data. The short sample period is of concern since it may weaken these tests.
} 
concern of potential regressors is, however, even greater than that of Wal-Mart's entrance: hence, including additional explanatory variables tends to magnify the problem. In alternatives, omitted variable bias emerges as a cost. It appears, however, that using county-level fixed effects significantly mitigates the effect of omitted variables over the study period since the fixed effects should capture the effects of any county-specific factors that do not change over time. The choice here then is one of selecting the lesser of evils. That is, we select the model specification that avoids exacerbating the larger problem of endogeneity, while mitigating the smaller problem of omitted variable bias.

Recognizing this, we estimate the impact using two instruments. The first, offered by Neumark, Zhang, and Ciccarrella (2008), takes the form:

$$
\Theta_{i, t}=\alpha+\alpha_{i}+\delta_{1} \operatorname{DIST}_{i}+\delta_{2}\left(\operatorname{DIST}_{i} \cdot T\right),
$$

in which the identification is accomplished with a fixed effect $\alpha_{\mathrm{i}}$, a distance variable DIST, and their product. We employ this instrumental variables approach estimated with 2SLS and include lagged exogenous variables within the instrument to account for the contemporaneous

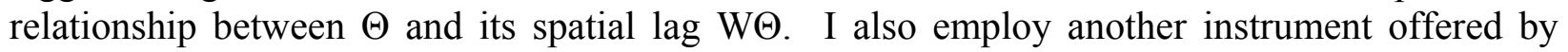
Hicks (2008) that identifies the treatment equation with a measure of total market size, defined as:

$$
\Theta_{i, t}=\alpha+\alpha_{i}+\delta_{1}\left(P I_{i}+\sum P I_{j}\right) .
$$

where $\alpha_{i}$ is the fixed effect for county $i, P I_{i}$ is the aggregate personal income in county $i$, and $\sum_{j=1}^{n} P I_{j}$ is the aggregate income across the $n$ contiguous counties. Both instruments were tested for weakness using a method recommended by Hausman and Hahn (2002). No evidence of a weak instrument problem is apparent in these tests. Additionally, these instruments have been employed in previously published research, and their weakness also has been rejected by Hicks (2008) and Neumark, Zhang, and Ciccarrella (2008).

We estimate impacts in Iowa's counties from 1988 through 2003, the available years of data from County Business Patterns when this paper was written. We compare results from both instruments and the ordinary least squares estimates across firm size in the three smallest categories of employers. Results appear in Table 2.

These estimates on the number of small retailers in Iowa generally reveal that no statistically meaningful impacts result from a new Wal-Mart. Moreover, in the one case where statistical significance is "close," the impact is positive (but nontrivially large). Wal-Marts in adjacent counties exert a very weak negative impact (though not statistically meaningful). This result in particular comports with conclusions from Hicks and Wilburn (2001), who found that a Wal-Mart in adjacent counties actually reduced own-county retail firms and employment in West Virginia.

We conducted two additional tests not reported here. We tested the model using a version of Basker's (2005a) instrument of planned entrance date (a two-year lead on entrance). Also, we changed the specification to account for per capita number of small businesses to provide equal exposure for each county. In both cases the results were not qualitatively different from those reported above. 
Table 2: Wal-Mart's Impact on Iowa's “Mom and Pop” Retailers ${ }^{3}$

\begin{tabular}{|c|c|c|c|c|c|c|c|c|c|}
\hline \multirow{2}{*}{$\begin{array}{l}\text { Firm Size } \\
\text { Instrument }\end{array}$} & \multicolumn{3}{|c|}{ 1-4 employees } & \multicolumn{3}{|c|}{ 5-9 employees } & \multicolumn{3}{|c|}{ 10-19 employees } \\
\hline & OLS & $\begin{array}{l}\text { Time } \\
\text { distance }\end{array}$ & $\begin{array}{l}\text { Market } \\
\text { Size }\end{array}$ & OLS & $\begin{array}{l}\text { Time } \\
\text { distance }\end{array}$ & $\begin{array}{l}\text { Market } \\
\text { Size }\end{array}$ & OLS & $\begin{array}{l}\text { Time } \\
\text { distance }\end{array}$ & $\begin{array}{l}\text { Market } \\
\text { Size }\end{array}$ \\
\hline $\begin{array}{l}\text { Common } \\
\text { intercept }\end{array}$ & $\begin{array}{l}25.66^{* * * *} \\
(5.05)\end{array}$ & $\begin{array}{l}2.866 \\
(0.204)\end{array}$ & $\begin{array}{l}-2.517 \\
(-0.19)\end{array}$ & $\begin{array}{l}26.41 * * * \\
(3.30)\end{array}$ & $\begin{array}{l}1.383 \\
(0.17)\end{array}$ & $\begin{array}{l}-2.874 \\
(-0.41)\end{array}$ & $\begin{array}{l}16.76^{* * *} \\
(3.49)\end{array}$ & $\begin{array}{l}-3.483 \\
(-0.10)\end{array}$ & $\begin{array}{l}1.497 \\
(0.08)\end{array}$ \\
\hline Wal-Mart & $\begin{array}{l}1.19 \\
(0.73)\end{array}$ & $\begin{array}{l}3.786 \\
(0.53)\end{array}$ & $\begin{array}{l}2.227 \\
(0.24)\end{array}$ & $\begin{array}{l}0.87 \\
(0.41)\end{array}$ & $\begin{array}{l}9.894 \dagger \\
(1.57)\end{array}$ & $\begin{array}{l}9.262 \\
(1.37)\end{array}$ & $\begin{array}{l}-2.34 * \\
(-1.75)\end{array}$ & $\begin{array}{l}42.261 \\
(0.39)\end{array}$ & $\begin{array}{l}75.171 \\
(0.19)\end{array}$ \\
\hline $\begin{array}{l}\text { Adjacent Wal- } \\
\text { Mart }\end{array}$ & $\begin{array}{l}4.76 \\
(1.17)\end{array}$ & $\begin{array}{l}-7.418 \\
(-0.58)\end{array}$ & $\begin{array}{l}-13.209 \\
(-0.75)\end{array}$ & $\begin{array}{l}1.26 \\
(0.52)\end{array}$ & $\begin{array}{l}-8.599 \\
(-1.09)\end{array}$ & $\begin{array}{l}-11.961 \\
(-0.98)\end{array}$ & $\begin{array}{l}-0.27 \\
(-0.31)\end{array}$ & $\begin{array}{l}-31.816 \\
(-0.50)\end{array}$ & $\begin{array}{l}-62.609 \\
(-0.19)\end{array}$ \\
\hline Spatial Lag & $\begin{array}{l}0.60 * * * \\
(7.90)\end{array}$ & $\begin{array}{l}0.991 * * * \\
(8.59)\end{array}$ & $\begin{array}{l}1.1327 * * * \\
(8.08)\end{array}$ & $\begin{array}{l}0.32 * * \\
(2.26)\end{array}$ & $\begin{array}{l}0.9608^{* * *} \\
(6.64)\end{array}$ & $\begin{array}{l}1.1187 * * * \\
(4.10)\end{array}$ & $\begin{array}{l}0.48^{* * *} \\
(3.87)\end{array}$ & $\begin{array}{l}0.998^{* * * *} \\
(3.65)\end{array}$ & $\begin{array}{l}0.833 \\
(0.80)\end{array}$ \\
\hline $\begin{array}{l}\text { Autoregressive } \\
\text { Component }\end{array}$ & $\begin{array}{l}0.88^{* * * *} \\
(9.49)\end{array}$ & $\begin{array}{l}0.830^{* * *} \\
(16.91)\end{array}$ & $\begin{array}{l}0.831^{* * * *} \\
(9.12)\end{array}$ & $\begin{array}{l}0.86^{* * *} \\
(14.9)\end{array}$ & $\begin{array}{l}0.850 * * * \\
(19.37)\end{array}$ & $\begin{array}{l}0.849 * * * \\
(15.15)\end{array}$ & $\begin{array}{l}0.67 * * * \\
(3.79)\end{array}$ & $\begin{array}{l}0.688^{* * *} \\
(7.84)\end{array}$ & $\begin{array}{l}0.675^{* * *} \\
(5.39)\end{array}$ \\
\hline Adjusted $\mathrm{R}^{2}$ & 0.98 & 0.98 & 0.98 & 0.99 & 0.98 & 0.98 & 0.98 & 0.97 & 0.93 \\
\hline Durbin-Watson & 2.27 & 2.26 & 2.26 & 2.39 & 2.40 & 2.40 & 1.95 & 2.00 & 1.99 \\
\hline Observations & 1,485 & 1,485 & 1,485 & 1,485 & 1,485 & 1,485 & 1,485 & 1,485 & 1,485 \\
\hline
\end{tabular}

Overall our results closely mirror those of Sobel and Dean (2008), who conclude, as do we, that there is no net impact of Wal-Mart on small retailers. Obviously, the OLS estimates offered here provide some contrasting results that cannot readily be explained. And, while the literature reveals some disagreement on the impact of Wal-Mart upon small retailers, even the most negative estimates (Basker, 2005a) reveal an impact that is remarkably modest.

The direction of impacts (albeit statistically immaterial) combined with the explanatory power of the spatial and temporal autocorrelation corrections point to a model that captures the salient elements of Wal-Mart's impact. They simply are too variable and small to point convincingly towards dramatic adjustments to retail industry structure attributable to Wal-Mart.

\section{SUMMARY AND CONCLUSIONS}

The considerable angst related to the putative impact of Wal-Mart on the structure of the retail sector-especially small businesses-warrants additional analysis. This paper provides a review of the development of this concern combined with an explanation of how contemporary research is addressing the real concerns of the treatment effects and endogeneity issues surrounding Wal-Mart's impact on local communities. This paper does not conclusively end the endogeneity debate prevalent in Wal-Mart studies. Indeed, the OLS results point to some potential for small business declines that are certainly correlated with the entrance of Wal-Mart. Still the lack of endogeneity with respect to Wal-Mart's entrance has been largely treated as suspect within a growing body of literature (see Basker, 2005a; Hicks, 2008; Neumark, Zhang, and Ciccarella, 2008).

\footnotetext{
${ }^{3}$ The Durbin-Watson panel statistic reported is derived from Bhargava, Franzini, and Narendranathan (1982). We white-washed the variance matrix using a version of Whites [1980] heteroskedastic consistent variance-covariance matrix derived from Driscoll and Kraay (1998). I do not report cross-sectional fixed effects.
} 
We built a treatment model of Wal-Mart on small retail businesses in Iowa and estimate a treatment model with alternative specifications and identification. We find no consequential impact of Wal-Mart on small business in Iowa from 1989-2003. There is some tepid evidence that an own-county Wal-Mart increases the number of small businesses, while counties adjacent to a county containing a new Wal-Mart tends to lose some small businesses. This result holds across two specifications and three different corrections for endogeneity. This result supports the retail agglomeration argument expressed in Hicks (2007) as one of the potentially observed WalMart-related phenomena.

As a cautionary note, these results do not speak to intra-county reallocation of commerce, which might be significant. Also, I use a standard firm-size measure, which imperfectly captures the possibility that these are additional chain stores, not local entrepreneurs. These data cannot speak clearly to that issue. Further, data limitations prevent a good accounting of the early impacts in Iowa (1983-1988) on which Stone (1989) focused his initial attention. I do examine the impacts subsequent to 1989, which Stone specifically noted in his study of businesses. Further, I do not address firm births and deaths, merely the annual numbers. Other studies (Hicks, 2007) have attempted to do this, finding no impact of Wal-Mart on gross firm flows in Pennsylvania; but this too remains an unanswered question in Iowa. Finally, Wal-Mart's potential impact on larger retail firms (including rival big-box stores) and on legal, accounting, and related administrative services centralized by Wal-Mart in Benton, Arkansas, should be considered. Basker (2005a) notes the loss of some large retail firms related to Wal-Mart's entrance, a finding that no doubt appears believable to anyone who owned stock in K-Mart or Sears during the 1990s.

Finally, these results place great pressure on policymakers considering limitations on Wal-Mart or other large retailers based upon potential local economic consequences. It is clear from these results and those of other studies reviewed here that a policy neutral approach to WalMart with respect to its effect on existing small business is the most prudent policy course.

\section{REFERENCES}

Artz, Georgeanne M. (1999) "The Impact of Wal-Mart on Retail Market Structure in Maine" unpublished Ph.D. thesis, University of Maine, Orono, Maine.

Artz, Georgeanne M. and James C. McConnon. (2001) “The Impact of Wal-Mart on Host Towns and Surrounding Communities in Maine," unpublished paper, University of Maine, Orono, Maine.

Barnes, Nora Ganim, Allison Connell, Lisa Hermenegildo, and Lucinda Mattson. (1996) "Regional Differences in the Economic Impact of Wal-Mart," Business Horizons, 39(4), 21-26.

Basker, Emek. (2005a) "Job Creation or Destruction? Labor Market Effects of Wal-Mart Expansion," Review of Economics and Statistics, 87, 174-183.

. (2005b) "Selling a Cheaper Mousetrap: Wal-Mart's Effect on Retail Prices," Journal of Urban Economics, 13, 4-27.

. 2007. "The Causes and Consequences of Wal-Mart's Growth," Journal of Economic Perspectives, 21(3), 177-198.

(C) Southern Regional Science Association 2010. 
Bhargava, Alok.,A., L. Franzini, Louisa and W. Narendranathan Wiji. (1982) "Serial Correlation and the Fixed Effects Models," Review of Economic Studies, 49, 533-549.

Davidson, Sharon M. and Amy Rummel. (2000) "Retail Changes Associated with Wal-Mart's Entry into Maine" International Journal of Retail \& Distribution Management, 28(4/5), $162-172$.

Driscoll, John and Art Kraay. (1998) "Consistent Covariance Matrix Estimation with Spatially Dependent Panel Data," Review of Economics and Statistics, 80, 549-560

Dube, Arindrajit, Barry Eidlin, and Bill Lester. (2006) "Impact of Wal-Mart Growth on Earnings throughout the Retail Sector in Urban and Rural Counties," Center for Labor Research and Education, Institute of Industrial Relations. University of California, Berkeley.

Franklin, Andrew W. (2001) "The Impact of Wal-Mart Supercenters on Supermarket Concentration in U.S. Metropolitan Areas," Agribusiness, 17, 105-114.

Franz, Lori and Edward Robb. (1989) "Effect of Wal-Mart Stores on the Economic Environment of Rural Communities," mimeo, University of Missouri.

Hahn, Jinyong and Jerry Hausman (2002): "A New Specification Test for the Validity of Instrumental Variables," Econometrica, 70, 163-189.

Hicks, Michael J. and Kristy Wilburn. (2001) "The Regional Impact of Wal-Mart Entrance: A Panel Study of the Retail Trade Sector in West Virginia," Review of Regional Studies, 31, 305-313.

. (2007) "Job Turnover and Wages in the Retail Sector: The Influence of Wal-Mart," Journal of Private Enterprise, 33, 137-160.

Hicks, Michael J. (2007) The Local Economic Impact of Wal-Mart. Cambria Press: New York.

. (2008) "Estimating Wal-Mart's Impacts in Maryland: a Test of Identification Strategies and Endogeneity Tests," Eastern Economic Journal, 33, 56-73.

Keon, Edward Robb and Lori Franz. (1989) "Effect of Wal-Mart Stores on the Economic Environment of Rural Communities," University of Missouri working paper.

Ketchum, Brian A. and James W. Hughes. (1997) "Wal-Mart and Maine: The Effect on Employment and Wages," mimeo, University of Maine.

McGee, Jeffrey E. and George G. Gresham. (1995) "When Wal-Mart Comes to Town: A Look at the Retailing Giant's Impact on Rural Communities," in William D. Bygrave, Barbara J. Bird, Sue Birley, Neil C. Churchill, Michael G. Hay, Robert H. Keeley, and William E. Wetzel, Jr. (eds), Frontiers of Entrepreneurship Research. Babson Foundation: Babson Park, MA. http://www.babson.edu/entrep/fer/papers95/mcgee.htm.

Neumark, David, Junfu Zhang, and Stephan Ciccarella. (2008) "The Effects of Wal-Mart on Local Labor Markets," Journal of Urban Economics, 63, 405-430

Ozment, John and Greg Martin. (1990) "Changes in the Competitive Environment of Rural Retail Trade Areas," Journal of Business Research, 21, 277-287.

Rigby, Darrel B. and Dan Haas (2004) “Outsmarting Wal-Mart” Harvard Business Review, December.

(C) Southern Regional Science Association 2010. 
Sobel, Russell S. and Andrea M. Dean. (2008) "Has Wal-Mart Buried Mom and Pop?: The Impact of Wal-Mart on Self- Employment and Small Establishments in the United States," Economic Inquiry, 46, 676-695.

Stone, Kenneth E. (1989) "The Effects of Wal-Mart Stores on Businesses in Host towns and Surrounding towns in Iowa," unpublished paper, Iowa State University, Ames. . (1995) Competing With the Retail Giants. John Wiley and Sons: New York.

- (1997) "Impact of the Wal-Mart Phenomenon on Rural Communities" Increasing Understanding of Public Problems and Policies, 1997.

Stone, Kenneth E., Georgeanne Artz, and Albert Myles (2002) "The Economic Impact of WalMart Supercenters on Existing Businesses in Mississippi," mimeo.

Stone, Kenneth E., Steven C. Deller, and James C. McConnon, Jr. (1992) "The New Retail Environment in Maine," Maine Business Research Report, 3(1), September.

Villareal, Pam. (2005) "Thinking Outside the 'Big Box'," Brief Analysis No. 501 National Center for Policy Analysis: Washington, DC, February 21.

White, Halbert. (1980) “A Heteroskedasticity-Consistent Covariance Matrix Estimator and a Direct Test for Heteroskedasticity," Econometrica, 1980, 48, 817-838.

Wilburn, Kristy. (1999) “The Effect of Wal-Mart Stores in Southern West Virginia," Regional Economic Review, Winter. 